\title{
Perbedaan Jumlah Telur Cacing Usus pada Selada (Lactuta sativa) yang Segar dan yang Disimpan selama Satu Minggu di Lemari Es
}

\author{
Nur Zahidah Nadzirah bt. Mohd. Pauzi ${ }^{1}$, Esther Sri Majawati \\ ${ }^{1}$ Mahasiswa Fakultas Kedokteran Universitas Kristen Krida Wacana \\ ${ }^{2}$ Staf Pengajar Bagian Parasitologi, Fakultas Kedokteran Universitas Kristen Krida Wacana \\ Alamat Korespondensi: esther.majawati@ukrida.ac.id
}

\begin{abstract}
Abstrak
Selada (Lactuta sativa) merupakan sayuran yang sering dikonsumsi secara mentah. Kebiasaan masyarakat gemar menyimpan bahan mentah di dalam lemari es karena tidak mau berulang kali ke pasar. Suhu bisa memengaruhi cepat atau lambatnya telur cacing menetas. Tujuan penelitian ini adalah untuk mengidentifikasi telur cacing usus pada selada dan melihat apakah ada perbedaan bermakna jumlah telur yang ditemukan pada selada segar dan selada yang disimpan selama satu minggu di dalam lemari es. Penelitian bersifat observasional dan kemudian dianalisis secara statistik. Diambil sebanyak 44 sampel selada dari penjual yang berbeda dari pasar tradisional di Tanjung Duren dan kawasan sekitarnya. Parameter yang diperiksa pada penelitian ini adalah telur cacing usus yang dapat dilihat pada pemeriksaan mikroskopik serta membandingkan hasil pemeriksaan antara selada segar dan selada yang disimpan selama satu minggu. Dari 44 bagian sampel selada segar yang diperiksa didapatkan telur cacing pada 24 sampel (55\%) dan pada 44 bagian sampel selada yang disimpan satu minggu didapatkan telur cacing pada 20 sampel (45\%). Hasil penelitian menunjukkan tidak ada perbedaan bermakna antara telur cacing usus yang didapatkan pada selada segar dan selada yang disimpan satu minggu di dalam lemari es.
\end{abstract}

Kata kunci: selada, telur cacing usus, pemeriksaan mikroskopik, Lactuca sativa

\section{Comparison of the Number of Intestinal Worm Egg Contamination between Fresh and Refrigerated Lettuce (Lactuca sativa)}

\begin{abstract}
Lettuce (Lactuta sativa) is a vegetable that is often eaten raw. People like to store raw vegetables in the refrigerator to keep them fresh, thus avoiding going to the market frequently. Temperature is known to affect worm egg hatching. Thus, the purpose of this research is to identify contamination of eggs of intestinal worms and protozoa in lettuce. And to evaluate the difference in the number of eggs on fresh lettuce and lettuce that had been refrigerated for one week. A total of 44 samples of lettuce were used, which were obtained from different vendors in traditional market in Tanjung Duren and the surrounding regions. Samples were examined for eggs of intestinal worms and protozoa by microscopic examination. The results between fresh lettuce and lettuce stored for a week were compared. Of the 44 samples of fresh lettuce, 24 samples (55\%) were contaminated by worm eggs, whereas of the refrigerated lettuce samples, 20 samples (45\%) were contaminated. The results showed no significant difference between fresh and refrigerated lettuce with regards to contamination of intestinal worm eggs and protozoa.
\end{abstract}

Keywords : lettuce, intestinal worm eggs, microscopic examination,Lactuca sativa 


\section{Pendahuluan}

Selada (Lactuta sativa) merupakan sayuran yang digemari. Selada keriting terutama mudah mudah ditemukan pada makanan asing seperti salad, hot dog, hamburger, dan sandwich. Makanan Indonesia juga banyak menggunakan selada contohnya gado-gado, lalapan nasi goring, dan lalapan pecel. Selada yang dimakan secara mentah ini dapat menjadi agen transmisi kista protozoa dan telur serta larva cacing usus. Ini dapat dikaitkan dengan penyakit kecacingan. ${ }^{1}$

Food-borne illness yang berkait dengan sayuran segar bisa terjadi akibat kontaminasi dengan telur cacing pada waktu masih dibudidayakan di kebun, pada waktu diproses, sewaktu dipasarkan, bahkan sewaktu di rumah. Hal ini terjadi karena pemupukan yang menggunakan pupuk kandang berasal dari kandang ternak berupa kotoran padat dicampur sisa makanan, atau tanaman disiram menggunakan air yang tidak bersih misalnya air limbah ternak, air sungai, atau air sawah yang tercemar telur cacing. ${ }^{2}$ Sering ditemukan nematoda usus yang ditularkan melalui tanah atau sering disebut Soil Transmitted Helminthes (STH) pada sayuran mentah. ${ }^{3}$ Terdapat beberapa jenis nematoda usus yang termasuk ke dalam STH yaitu cacing gelang (Ascaris lumbricoides), cacing tambang (Ancylostoma duodenale dan Necator americanus), cacing cambuk (Trichuris trichiura), dan beberapa spesies Tricostrongylus. ${ }^{3}$

Beberapa survei yang dilakukan di Indonesia menunjukkan bahwa seringkali prevalensi Ascaris yang tinggi disertai prevalensi Trichuris. ${ }^{3}$ Telur A. lumbicoides yang telah dibuahi dan jatuh di tanah yang sesuai menjadi matang dalam waktu tiga minggu pada suhu optimum $25^{\circ}-30^{\circ} \mathrm{C} .^{3}$ Telur $T$. trichiura akan matang dalam waktu 36 minggu pada suhu optimum sekitar $30^{\circ} \mathrm{C} .^{3}$ Telur matang kedua spesies ini tidak menetas dalam tanah dan dapat bertahan hidup beberapa tahun, khususnya telur $A$. lumbricoides. ${ }^{3}$ Selain tanah dan iklim yang sesuai, keadaan endemik juga dipengaruhi jumlah telur yang dapat hidup sampai menjadi bentuk infektif dan masuk ke dalam tubuh hospes. ${ }^{3}$ Di dalam hospes, larva akan menjadi cacing dewasa di usus halus. ${ }^{3}$

Daun selada berposisi duduk sehingga dapat kontak langsung dengan tanah. ${ }^{4,5}$ Hal ini memungkinkan STH yang berada di tanah akan mudah menempel pada daun selada., Selama periode penanaman sayur juga terdapat pengaruh lingkungan yang memungkinkan terjadinya ketidakamanan pangan dan terdapat sisa-sisa kotoran, sehingga pencucian mutlak diperlukan sebelum sayur dikonsumsi. ${ }^{4,5}$ Penggunaan air sebagai media untuk mencuci sayuran dimungkinkan memiliki pengaruh terhadap terjadinya kontaminasi. ${ }^{4,5}$ Pencucian yang dilakukan pada sayuran dapat mengurangi atau bahkan menambah jasad renik (telur cacing), tergantung pada cara pencucian, jenis sayuran, dan mutu air pencuci. Kualitas air yang digunakan untuk membersihkan mutlak diperlukan. Pencucian yang benar adalah dengan air mengalir sehingga dapat membersihkan sisa kotoran dengan maksimal., ${ }^{4,5}$ Masyarakat di Indonesia terbiasa mengonsumsi sayuran sebagai lalapan mentah dan lalapan memunyai risiko untuk terkontaminasi parasit. ${ }^{4,5}$

Sayuran daun memunyai permukaan yang berlekuk daripada sayuran buah, sehingga telur cacing yang menempel pada sayuran daun lebih sulit dibersihkan. ${ }^{6}$ Untuk menghindari telur yang melekat dalam sayuran masuk ke dalam tubuh, sebelum dikonsumsi, selada terlebih dahulu harus dibersihkan dengan cara melepaskan daun selada satu per satu dari batangnya, kemudian dibersihkan air keran yang mengalir yang bersih. ${ }^{6}$ Dalam melakukan identifikasi telur cacing usus, digunakan metoda pemeriksaan secara tidak langsung yaitu dengan teknik sedimentasi atau teknik pengendapan sederhana. ${ }^{7}$ Teknik ini memerlukan waktu yang lama tetapi memunyai keuntungan, karena dapat mengendapkan telur tanpa merusak bentuknya. $^{7}$

Kebiasaan masyarakat juga gemar menyimpan bahan mentah seperti sayuran di dalam lemari es karena tidak mau berulang kali ke pasar. Suhu bisa memengaruhi cepat atau lambatnya telur cacing menetas. ${ }^{3}$ Tujuan penelitian ini adalah untuk mengidentifikasi telur cacing usus pada selada, dan melihat apakah ada perbedaan pada telur tersebut jika selada disimpan selama satu minggu di dalam lemari es.

\section{Metodologi Penelitian}

\section{Bahan Penelitian}


Selada yang dibeli dari penjual yang berlainan di pasar tradisional.

Prosedur

Pemeriksaan telur cacing pada penelitian ini menggunakan metode tak langsung dengan teknik sedimentasi (pengendapan). Prosedur pemeriksaannya yaitu: selada yang dibeli dari seorang penjual dibagi dua: satu bagian diperiksa langsung dan satu bagian lagi disimpan di dalam lemari es. Selada diperiksa setelah dipotong menjadi bagian kecil-kecil. Selada sebanyak 50 gram direndam dengan $50 \mathrm{ml}$ air keran di dalam beaker glass $1000 \mathrm{ml}$. Setelah satu jam, selada diangkat diaduk dengan pinset lalu dikeluarkan. Air rendaman kemudian disaring dan dimasukkan ke dalam beaker glass lain dan didiamkan selama satu jam. Air yang di permukaan beaker glass dibuang, air di bagian bawah beaker glass beserta endapannya diambil dengan volume $10 \mathrm{ml}$ menggunakan pipet dan dimasukkan ke dalam tabung sentrifugasi disentrifugasi dengan kecepatan 1.500 putaran/ menit selama lima menit. Membuang supernatant, endapan bagian bawah diambil untuk diperiksa secara mikroskopis dengan pembesaran 100x dan 400x. Satu minggu kemudian, langkahlangkah seperti di atas diulang untuk mengidentifikasi telur cacing pada selada yang telah disimpan selama satu minggu di dalam lemari es.

\section{Analisis Statistik}

Analisis data yang digunakan pada penelitian ini adalah analisis deskriptif dan disajikan dalam bentuk tabel. Untuk menguji hipotesis penelitian, menggunakan Pearson Chi-square dengan aplikasi komputer program SPSS 18.0.

\section{Hasil Penelitian}

Dalam penelitian ini, diambil sampel dari 44 penjual dari pasar yang berbeda di Tanjung Duren dan kawasan sekitarnya. Dari hasil penelitian, ditemukan hasil sebagai berikut (Tabel 1-6):
Tabel 1. Distribusi Frekuensi Telur Cacing pada Selada Segar yang Dijual di Pasar Tradisional di Tanjung Duren dan Sekitarnya.

\begin{tabular}{lcc}
\hline \multirow{2}{*}{ Hasil } & \multicolumn{2}{c}{ Frekuensi } \\
\cline { 2 - 3 } pemeriksaan & $\mathrm{n}$ & $\%$ \\
\hline Positif $(+)$ & 24 & 55 \\
Negatif $(-)$ & 20 & 45 \\
\hline Jumlah & 44 & 100 \\
\hline
\end{tabular}

Tabel 2 . Distribusi Frekuensi Telur Cacing pada Selada setelah Disimpan Satu Minggu yang Dijual di Pasar Tradisional di Tanjung Duren dan Sekitarnya.

\begin{tabular}{lcc}
\hline \multirow{2}{*}{ Hasil } & \multicolumn{2}{c}{ Frekuensi } \\
\cline { 2 - 3 } pemeriksaan & $\mathrm{n}$ & $\%$ \\
\hline Positif $(+)$ & 20 & 45 \\
Negatif $(-)$ & 24 & 55 \\
\hline Jumlah & 44 & 100 \\
\hline
\end{tabular}

Tabel 3. Persentase Jenis Telur Cacing yang terdapat pada Selada Segar yang Dijual di Pasar Tradisional di Tanjung Duren dan Sekitarnya.

\begin{tabular}{lll}
\hline \multirow{2}{*}{ Jenis } & \multicolumn{2}{c}{ Frekuensi } \\
\cline { 2 - 3 } & $\mathrm{n}$ & $\%$ \\
\hline Telur Ascaris lumbricoides & 21 & 88 \\
Telur Cacing Tambang & 3 & 12 \\
\hline Jumlah & 24 & 100 \\
\hline
\end{tabular}

Tabel 4. Persentase Jenis Telur Cacing yang terdapat pada Selada Setelah Disimpan Satu Minggu yang Dijual di Pasar Tradisional di Tanjung Duren dan Sekitarnya.

\begin{tabular}{lll}
\hline \multirow{2}{*}{ Jenis } & \multicolumn{2}{c}{ Frekuensi } \\
\cline { 2 - 3 } & $\mathrm{n}$ & $\%$ \\
\hline Telur Ascaris lumbricoides & 18 & 90 \\
Telur Cacing Tambang & 2 & 10 \\
\hline Jumlah & 20 & 100 \\
\hline
\end{tabular}


Tabel 5 . Persentase Distribusi Telur Cacing yang terdapat pada Selada Segar dan Setelah Disimpan Satu Minggu yang Dijual di Pasar Tradisional di Tanjung Duren dan Kawasan Sekitarnya.

\begin{tabular}{lcc}
\hline \multicolumn{1}{c}{ Hasil } & \multicolumn{2}{c}{ Persentase (\%) } \\
\cline { 2 - 3 } Pemeriksaan & Selada segar & Selada disimpan seminggu \\
\hline Positif & 55 & 45 \\
Negatif & 45 & 55 \\
\hline Jumlah & 100 & 100 \\
\hline
\end{tabular}

Tabel 6 . Persentase jenis Telur Cacing yang Terdapat pada Selada Segar dan Setelah Disimpan Satu Minggu yang Dijual di Pasar Tradisional di Tanjung Duren dan Kawasan Sekitarnya.

\begin{tabular}{lcccc}
\hline \multirow{2}{*}{ Jenis } & \multicolumn{2}{c}{ Frekuensi } & \multicolumn{2}{c}{ Persentase \% } \\
\cline { 2 - 5 } & $\begin{array}{c}\text { Selada } \\
\text { segar }\end{array}$ & $\begin{array}{c}\text { Selada disimpan } \\
\text { satu minggu }\end{array}$ & $\begin{array}{c}\text { Selada } \\
\text { Segar }\end{array}$ & $\begin{array}{c}\text { Selada disimpan } \\
\text { satu minggu }\end{array}$ \\
\hline Telur Ascaris sp & 21 & 18 & 88 & 90 \\
Telur Cacing Tambang & 3 & 2 & 12 & 10 \\
\hline Jumlah & 24 & 20 & 100 & 100 \\
\hline
\end{tabular}

Data kemudian dianalisis dengan uji Pearson Chi-square dengan aplikasi komputer SPSS Window 16.0.

Hasil yang didapatkan adalah tidak ada perbedaan yang bermakna pada hasil pemeriksaan telur cacing usus pada selada segar dan selada yang telah disimpan satu minggu.

\section{Pembahasan}

Hasil menunjukkan tidak ada perbedaan yang bermakna antara jumlah sampel positif telur cacing usus pada selada segar dan selada yang disimpan satu minggu. Telur matang $A$. lumbricoides umumnya dapat bertahan hidup selama beberapa tahun dalam udara dingin, panas, maupun kekeringan sedangkan bagi cacing tambang hanya bisa bertahan selama kira-kira 7-8 minggu. Suhu lemari es yang ideal adalah $3^{\circ} \mathrm{C}$. Suhu ini merupakan suhu yang rendah dari suhu optimum bentuk infektif cacing, tetapi karena daya tahan hidup telur cacing yang tinggi, maka apabila selada yang mengandungi telur cacing disimpan di dalam lemari es selama satu minggu, tidak ada perubahan atau perbedaan yang bermakna dibandingkan dengan hasil pemeriksaan telur cacing pada selada segar. ${ }^{3}$

Hasil pemeriksaan positif telur cacing pada penelitian ini dapat disebabkan karena selada biasanya ditanam berposisi duduk sehingga kontak langsung dengan tanah, jadi memungkinkan telur STH yang berada di tanah sering ditemukan menempel pada daun selada terutama bagian krop terluar dan ujung bagian selada. ${ }^{8}$ Selada di pasar tradisional juga diletakkan terbuka di atas meja atau di kantong plastik besar atau karung dan sering diletakkan sembarangan. Faktor lain yang dapat memengaruhi keberadaan telur cacing pada selada seperti penggunaan pupuk organik yang berasal dari ternak sebagai media penyuburan sayuran. Sama halnya seperti pada manusia, jika kotoran ternak tersebut mengandung telur cacing maka dengan mudahnya telur yang ada di dalam kotoran ternak akan berpindah ke daun selada yang kontak langsung dengan tanah. ${ }^{1}$

Jenis telur cacing yang ditemukan adalah STH (Ascaris sp dan cacing tambang). Kemungkinan telur Ascaris yang ditemukan adalah Ascaris lumbricoides. Telur Ascaris merupakan yang paling banyak ditemukan pada penelitian ini dibandingkan dengan telur cacing tambang, karena telur Ascaris dapat hidup berbulan-bulan di dalam air selokan dan tinja. ${ }^{3}$ Selada dapat ditanam pada berbagai jenis tanah tetapi pertumbuhan yang baik bila ditanam di tanah yang gembur, lembab, dan mengandung cukup bahan organik. Diasumsikan bahwa selada dan STH hidup dalam kondisi tanah yang serupa. Penggunaan air penyiram yang tercemar telur cacing serta 
penyiraman air atau air hujan dapat menyebabkan tanaman terpercik tanah yang mengandung telur cacing, sehingga telur cacing tersebut menempel pada selada. Infeksi cacing dapat menyebabkan gejala klinis pada manusia jika terinfeksi dalam jumlah banyak dan daya tahan tubuh rendah. ${ }^{3}$

Dari 44 selada yang diperiksa, telur cacing tambang hanya ditemukan $3(12 \%)$ pada selada segar dan $2(10 \%)$ pada selada yang disimpan satu minggu. Frekuensi yang sedikit ini dapat disebabkan karena faktor jenis tanah dan suhu. Berbeda dengan STH lainnya, telur cacing tambang dapat tumbuh optimum pada lingkungan yang mengandung pasir, karena pasir memiliki berat jenis yang lebih besar daripada air sehingga telur-telur akan terlindung dari sinar matahari. Suhu juga merupakan faktor yang memengaruhi pertumbuhan cacing tambang. Suhu optimum pertumbuhan cacing tambang yaitu $32^{\circ} \mathrm{C}$, tetapi suhu daerah perkebunan selada lebih dingin yaitu berkisar antara $15^{\circ} \mathrm{C}-23^{\circ} \mathrm{C}$, sehingga tidak baik untuk pertumbuhan cacing tambang. Namun beberapa telur cacing memunyai kemampuan adaptasi tinggi sehingga dapat tetap bertahan meskipun perkembangannya tidak optimal. ${ }^{1}$

Telur cacing tambang pada penelitian ini dapat berasal dari cacing tambang pada manusia yaitu Necator americanus dan Ancylostoma duodenale, karena bentuk keduanya tidak dapat dibedakan melalui pemeriksaan langsung dengan mikroskop. Selain itu, telur cacing tambang dapat juga berasal dari kucing atau anjing yaitu Ancylostoma braziliense, Ancylostoma ceylanicum, dan Ancylostoma caninum. Adanya tinja yang berdekatan dengan tanaman dan adanya air hujan menyebabkan larutnya tinja dan membawa telur cacing untuk melekat di daun selada. ${ }^{3}$ Apabila telur cacing masih melekat pada daun selada, dan dikonsumsi dalam keadaan mentah dapat terjadi kecacingan.

Jumlah telur cacing yang ditemukan ini lebih sedikit dibandingkan dengan penelitian sebelumnya yang pernah dilakukan di Kota Padang. ${ }^{1}$ Telur Ascaris adalah yang paling banyak ditemukan, diikuti telur cacing tambang, dan larva Trichostrongylus orientalis, diduga akibat kontaminasi juga berasal dari teknik pencucian yang kurang tepat. $^{1}$
Penelitian ini dapat menjelaskan kepada kita bahwa selada sangat berpotensi untuk penularan penyakit yang disebabkan oleh STH. Maka dalam hal ini sangat diperlukan usaha pencegahan. Untuk menghindar agar STH yang terdapat pada sayuran tidak masuk ke tubuh, maka tindakan preventif yang dapat dilakukan adalah pencucian selada dengan air mengalir, karena dapat menghilangkan STH yang menempel pada daun selada sebanyak 94\%. ${ }^{9}$

Demikian pula sayur-sayuran yang lain, bahkan yang dijual di supermarket pun dapat terkontaminasi telur cacing. ${ }^{10}$ Selain telur cacing, selada dari pasar di daerah sekitarnya juga pernah ditemukan terkontaminasi dengan Escherichia coli fekal. ${ }^{11}$

\section{Simpulan}

Dari penelitian yang dilakukan di pasar tradisional di daerah Tanjung Duren dan kawasan sekitarnya, ditemukan hasil pemeriksaan telur cacing positif pada selada segar dan selada yang disimpan selama satu minggu di dalam lemari es. Oleh karena itu, selada berpotensi untuk menyebabkan penyakit pada manusia. Untuk mencegah terinfeksi, lakukan pencucian daun sayuran satu per satu menggunakan air keran yang mengalir sebelum mengonsumsinya.

\section{Daftar Pustaka}

1. Asihka V, Nurhayati N, Gayatri G. Distribusi frekuensi Soil Transmitted Helminth pada sayuran selada yang dijual di pasar tradisional dan pasar modern di Kota Padang. [Online]. Diunduh dari http://jurnal.fk.unand.ac.id. pada 12 Februari 2017.

2. Syarifah A. Pemeriksaan telur cacing Ascaris lumbricoides pada daun selada yang diperjual belikan di pasar tradisional Binjai tahun 2011. [Online] Akedemi Analisis Kesehatan STIKes Mutiara Indonesia Medan. 2011. Diunduh dari http://www.academia.edu/17014565/Daft ar isi sth selada pada 12 Februari 2017.

3. Supali $\mathrm{T}$, Margono SS, Abidin SAN. 2011. Nematoda usus. Dalam Sutanto I, Ismid IS, Sjarifuddin PK, Saleha S.(Eds). Buku ajar parasitologi kedokteran. Edisi keempat. Jakarta. Badan Penerbit FKUI;h.6-24. 
4. Widjaja J, Lob LT, Oktaviani. Prevalensi dan jenis telur cacing soil transmitted helminths (STH) pada sayuran kemangi pedagang ikan bakar di Kota Palu. [Jurnal online] 2014 Desember 5(2):61-6 Diunduh dari http://ejournal.litbang.depkes.go.id/index. php/buski/article/view/3625 pada 21 Januari 2017.

5. Lobo LT, Widjadja J, Octaviani, Puryadi. Kontaminasi telur cacing SoilTransmitted Helmints (STH) pada sayuran kemangi pedagang ikan bakar di kota Palu Sulawesi Tengah. Media Litbangkes. 2016; 26(2): 65-70.

6. Purba SF, Chahaya I, Marsaulina I, Pemeriksaan Escherichia coli dan larva cacing pada sayuran lalapan kemangi (Ocimum basilicum), kol (Brassica oleracea L.var.capotata.L.), selada (Lactuta sativa L.), terong (Solanum melongena) yang dijual di pasar tradisional, supermarket dan restoran di Kota Medan tahun 2012. [Jurnal] Department Kesehatan Lingkungan Universitas Sumatera Utara. 2012.

7. Nugroh C, Djanah SN, Mulasari SA.
Identifikasi kontaminasi telur nematoda usus pada sayuran kubis (Brassica leracea) warung makan lesehan Wonosari Gunungkidul Yogyakarta tahun 2010. [Jurnal Online] Fakultas Kesehatan Masyarakat, Universitas Ahmad Dahlan, Yogyakarta. 2010. Diunduh dari file://C:/Users/USER/Desktop/Download s/557-1965-1-PB.pdf pada 12 Februari 2017.

8. Purnomo, Gunawan JW, Magdalena LJ, Ayda R, Harrijani AM. Atlas helmintologi kedokteran. Jakarta. Penerbit PT Gramedia: 2005.h.2-15.

9. Doaa ES. Detection of parasites in commonly consumed raw vegetables. [artikel]. Egypt: Faculty of Medicine, Alexandria. 25 September 2012.

10. Yahyadi JV, Majawati ES, Simamora A. Identifikasi telur cacing pada kubis (Brassica oleraceae) pada pasar swalayan. J Kedokt. Meditek. 2017;23(62):35-9.

11. Olianovi N, Pasaribu DMR. Menghitung Escherichia coli fekal dari air cucian selada di pasar wilayah kecamatan grogol. J Kedokt. Meditek. 2017;23(61):23-31. 